University of Nebraska - Lincoln

DigitalCommons@University of Nebraska - Lincoln

$1-14-2004$

\title{
Estimation of Carbon Sequestration by Combining Remote Sensing and Net Ecosystem Exchange Data for Northern Mixed- Grass Prairie and Sagebrush-Steppe Ecosystems
}

\author{
E. Raymond Hunt Jr. \\ USDA-ARS, Beltaville, Maryland \\ Robert D. Kelly \\ University of Wyoming \\ William K. Smith \\ Wake Forest University \\ Jace T. Fahnestock \\ Colorado State University - Fort Collins \\ Jeffrey M. Welker \\ Colorado State University - Fort Collins
}

See next page for additional authors

Follow this and additional works at: https://digitalcommons.unl.edu/usdaarsfacpub

Part of the Agricultural Science Commons

Hunt, E. Raymond Jr.; Kelly, Robert D.; Smith, William K.; Fahnestock, Jace T.; Welker, Jeffrey M.; and Reiners, William A., "Estimation of Carbon Sequestration by Combining Remote Sensing and Net Ecosystem Exchange Data for Northern Mixed-Grass Prairie and Sagebrush-Steppe Ecosystems" (2004). Publications from USDA-ARS / UNL Faculty. 306.

https://digitalcommons.unl.edu/usdaarsfacpub/306

This Article is brought to you for free and open access by the U.S. Department of Agriculture: Agricultural Research Service, Lincoln, Nebraska at DigitalCommons@University of Nebraska - Lincoln. It has been accepted for inclusion in Publications from USDA-ARS / UNL Faculty by an authorized administrator of DigitalCommons@University of Nebraska - Lincoln. 


\section{Authors}

E. Raymond Hunt Jr., Robert D. Kelly, William K. Smith, Jace T. Fahnestock, Jeffrey M. Welker, and William A. Reiners 


\section{Estimation of Carbon Sequestration by Combining Remote Sensing and Net Ecosystem Exchange Data for Northern Mixed-Grass Prairie and Sagebrush-Steppe Ecosystems}

\author{
E. RAYMOND HUNT, JR.* \\ Hydrology and Remote Sensing Laboratory \\ USDA-ARS \\ Building 007 Room 104, 10300 Baltimore Avenue \\ Beltsville, Maryland 20705-2350, USA
}

ROBERT D. KELLY

Department of Atmospheric Sciences

University of Wyoming

PO Box 3038

Laramie, Wyoming 82071-3038, USA

\section{WILLIAM K. SMITH}

Department of Biology

Wake Forest University

PO Box 7325

Winston-Salem, North Carolina 27109-7325, USA

\section{JACE T. FAHNESTOCK \\ JEFFREY M. WELKER}

Natural Resource Ecology Laboratory

Colorado State University

Fort Collins, Colorado 80523-1499, USA

WILLIAM A. REINERS

Department of Botany

University of Wyoming

PO Box 3165

Laramie, Wyoming 82071-3165, USA
ABSTRACT / Carbon sequestration was estimated a northern mixed-grass prairie site and a sagebrush-steppe site in southeastern Wyoming using an approach that integrates remote sensing, $\mathrm{CO}_{2}$ flux measurements, and meteorological data. Net ecosystem exchange (NEE) of $\mathrm{CO}_{2}$ was measured using aircraft and ground flux techniques and was linearly related to absorbed photosynthetically active radiation (APAR). The slope of this relationship is the radiation use efficiency ( $\varepsilon=0.51 \mathrm{~g} \mathrm{C} / \mathrm{MJ}$ APAR); there were no significant differences in the regression coefficients between the two sites. Furthermore, ecosystem chamber measurements of total respiration in 1998 and 1999 were used to develop a functional relationship with daily average temperature; the $Q_{10}$ of the relationship was 2.2. Using the Advanced Very High Resolution radiometer. Normalized Difference Vegetation Index and meteorological data, annual gross primary production and respiration were calculated from 1995 to 1999 for the two sites. Overall, the sagebrush-steppe site was a net carbon sink, whereas the northern mixed-grass prairie site was in carbon balance. There was no significant relationship between NEE and APAR for a coniferous forest site, indicating this method for scaling up $\mathrm{CO}_{2}$ flux data may be only applicable to rangeland ecosystems. The combination of remote sensing with data from $\mathrm{CO}_{2}$ flux networks can be used to estimate carbon sequestration regionally in rangeland ecosystems.
Natural resource management may be altered to offset $\mathrm{CO}_{2}$ emissions from fossil fuels (Paustian and others 1998, Follett and others 2001). Rangelands are a type of natural resource comprised of a variety of ecosystems, such as shrublands and grasslands, that cover large areas of the United States of America and the

KEY WORDS: Net ecosystem exchange; NDVI: Absorbed photosynthetically active radiation; Radiation use efficiency; Sagebrush-steppe; Northern mixed-grass prairie

Published online January 14, 2004.

*Author to whom correspondence should be addressed, email: erhunt@hydrolab.arsusda.gov world (Follett and others 2001). Small, cost-effective changes applied to large areas of rangeland may result in significant offsets of $\mathrm{CO}_{2}$ emissions (Follett and others 2001). Because the landscape is extremely heterogeneous, where each location uniquely represents different combinations of topography, soils, ecosystem type, land-use history, and other variables, estimates of total carbon may vary greatly. As a baseline for future changes, estimates of current rates of carbon sequestration are required, preferably over several years, to account for natural climatic variability.

Many methods may be used to estimate carbon sequestration, with each method having both advantages and disadvantages; however, two methods are designed 
to provide estimates at larger spatial scales. The first method involves the measurement of net ecosystem exchange (NEE) of $\mathrm{CO}_{2}$. NEE is the sum of different ecosystem fluxes, particularly gross primary production (GPP), autotrophic respiration, and heterotrophic respiration. Methods for determining NEE range from small, enclosed ecosystem chambers (Angell and Svejcar 1999, Angell and others 2001) to eddy-flux aircraft that can cover hundreds of square kilometers. Advances in technology and theory (Goulden and others 1996, Baldocchi and others 1996) have led to international efforts such as the Ameriflux and Euroflux networks. Furthermore, the USDA-ARS Rangeland $\mathrm{CO}_{2}$ Flux Network is providing estimates of NEE for various rangeland ecosystems of the western United States (Svejcar and others 1997, Frank and others 2001).

The second method for estimating carbon sequestration at large spatial scales involves remote sensing to monitor vegetation with sensors such as the Advanced Very High Resolution Radiometer (AVHRR) and the Moderate Resolution Imaging Spectrometer (MODIS). Development and testing of algorithms relating satellite data to land-surface properties was the rationale for major experiments such as the First ISLSCP Field Experiment (Sellers and others 1992) and the Boreal Ecosystem-Atmosphere Study (Sellers and others 1997). The current methodology for estimating GPP from satellites is to estimate the amount of photosynthetically active radiation absorbed by the canopy (APAR) from remotely sensed vegetation indices and incident radiation (Hunt and Running 1992, Running and Hunt 1993, Prince and Goward 1995, Ruimy and others 1995, Waring and others 1995, Landsberg and Waring 1997, Goetz and Prince 1999, Wylie and others 2003, Hunt and others 2003). An important attribute of remotely sensed data is that important vegetation properties are known over the entire area; consequently, replication and sampling are not necessary at these large scales, because the entire "population" is measured by the satellite. However, satellite estimates of GPP and other ecosystem fluxes may not be very accurate.

The idea of combining remotely sensed and ecosystem-flux data has been discussed several times (Ruimy and others 1995, 1996, Running and others 1999, Hunt and others 2002, Wylie and others 2003). Here we show that net ecosystem exchange (NEE) of $\mathrm{CO}_{2}$ from flux aircraft and ecosystem chamber measurements can be used to determine directly radiation use efficiency. We then test this method for two ecosystems in southeastern Wyoming, USA: a northern mixed-grass prairie grassland and a sagebrush-steppe shrubland.

\section{Background and Theory}

Radiation use efficiency is usually defined as the amount of photosynthetic production per unit of radiation absorbed, with different operational definitions used depending on the specific situation and research objectives. For this study, the efficiency of radiation use was defined as the mass of carbon uptake per absorbed photosynthetically active radiation (APAR) from 400 $\mathrm{nm}$ to $700 \mathrm{~nm}$ wavelength. Following Ruimy and others (1995), gross primary production (GPP, $\mathrm{g} \mathrm{Cm}^{-2}$ time $^{-1}$ ) is summed over an arbitrary time period from instantaneous fluxes to annual totals:

$$
\mathrm{GPP}=\varepsilon \sum \mathrm{APAR}
$$

where $\varepsilon$ is the efficiency of radiation use $(\mathrm{g} \mathrm{C} / \mathrm{MJ}$ APAR) and APAR has units of $\mathrm{MJm}^{-2}$ time $^{-1}$. Often APAR is approximated by either intercepted photosynthetically active radiation or intercepted solar radiation (Prince 1991, Running and Hunt 1993, Gower and others 1999). Other operational definitions of $\varepsilon$ incorporate either net primary production or above-ground net primary production; thus, autotrophic respiration and carbon allocation are incorporated in the value of $\varepsilon$ (Prince 1991, Hunt and Running 1992, Running and Hunt 1993, Hunt 1994, Ruimy and others 1994, Gower and others 1999).

For actual growth conditions, $\varepsilon$ will be reduced from the maximum because of stomatal closure caused by drought, large vapor pressure differences between leaf and air, nighttime temperatures falling below freezing, air pollution, and other stresses that affect photosynthesis.

Furthermore, Ruimy and others (1995) concluded that $\varepsilon$ was reduced, usually by about $50 \%$, from the photosynthetic capacity of the foliage being light saturated (however, see Goetz and Prince 1999). Nitrogen stress is another factor that affects $\varepsilon$ (Sinclair and Horie 1989, Sinclair and Muchow 1999), which also may be remotely sensed using visible and near-infrared bands (Daughtry and others 2000).

The fraction of incident photosynthetically active radiation (PAR) that is absorbed ( $f_{\mathrm{APAR}}$, dimensionless) is a quantity that can be estimated from remotely sensed vegetation indices. The vegetation index most often used is the Normalized Difference Vegetation Index (NDVI):

$$
\text { NDVI }=(\text { NIR }- \text { Red }) /(\text { NIR }+ \text { Red })
$$

where NIR is the spectral radiance from a near-infrared wavelength band and Red is the spectral radiance from a red wavelength band. Originally, NDVI was developed to enhance the distinction between vegetation and soil 
and to reduce the effects of atmospheric transmittance, topography, and solar elevation and azimuth (Rouse and others 1974). Subsequently, Asrar and others (1984) and other studies showed that NDVI was approximately equal to $f_{\mathrm{APAR}}$. NDVIs from AVHRR onboard meteorological satellites are most often used in models of $\varepsilon$, because these data are collected daily and composited weekly or biweekly to generate nearly cloud-free images over a growing season. The amount of green leaf area index changes rapidly with soil moisture conditions in rangelands, and AVHRR NDVI data can capture these dynamics (Hunt and others 2003, Wylie and others 2003). The main disadvantages of AVHRR data are the large pixel sizes $(1 \mathrm{~km})$ and some artifacts (Gutman 1991, 1999, Cihlar and others 1997).

Detailed canopy radiative transfer models are now used to determine $f_{\mathrm{APAR}}$ from NDVI (Baret and Guyot 1991, Goward and Huemmrich 1992, Ruimy and others 1994, Myneni and Williams 1994). For this study, the nonlinear relationship between NDVI and $f_{\text {APAR }}$ was linearly approximated (Ruimy and others 1994):

$$
f_{\mathrm{APAR}}=1.25 \mathrm{NDVI}-0.10
$$

The constant value of 0.10 was determined from the minimum value of AVHRR NDVI data during snow-free winter periods. Therefore, if $\varepsilon$ is known, GPP over a compositing period can be calculated from average incident PAR and remotely sensed NDVI:

$$
\mathrm{GPP}=\varepsilon \sum n(1.25 \mathrm{NDVI}-0.10) \mathrm{PAR}
$$

where $n$ is the number of days of the AVHRR compositing period.

Autotrophic respiration is the sum of all plant respiration, usually separated into growth and maintenance respiration. Heterotrophic respiration is the sum of respiration by animals, fungi and bacteria and is most closely associated with the decomposition of residue and soil organic matter. The relative contributions of autotrophic and heterotrophic respiration to the total are important, but cannot be separated using only soilsurface carbon exchange rates (Hanson and others 2000). Net ecosystem exchange (NEE, g Cm ${ }^{-2}$ time $^{-1}$ ) is defined as:

$$
\mathrm{NEE}=\mathrm{GPP}-R_{\text {total }}
$$

where $R_{\text {total }}\left(\mathrm{g} \mathrm{Cm}^{-2}\right.$ time $\left.^{-1}\right)$ is the sum of all autotrophic respiration and heterotrophic respiration over some time period from instantaneous fluxes to annual totals. Replacing GPP in equation 5, with equation 1 above, leads to:

$$
\mathrm{NEE}=\varepsilon \sum \mathrm{APAR}-\mathrm{R}_{\text {total }}
$$

Equation 6 shows that when NEE is regressed against $\Sigma$ APAR for short time intervals, the slope of the line should equal mean $\varepsilon$ and the intercept should equal mean $R_{\text {total }}$ (Ruimy and others 1995). Thus, the main parameter $\varepsilon$ may be estimated directly from NEE data, without using elaborate ecosystem models.

However, GPP is only one of the carbon cycle processes that affect carbon sequestration. Because $R_{\text {total }}$, when calculated from a regression of NEE versus APAR using equation 6 , will usually not include wintertime and nighttime carbon exchange measurements, $R_{\text {total }}$ can not then be used to estimate the amount of carbon sequestered, presumably as soil organic matter. Thus, the annual sum of autotrophic and heterotrophic respiration must be estimated using either simple or complex models driven by climatic data (Hunt and others 1996).

\section{Methods}

Two sites in southeastern Wyoming, USA, were originally selected to estimate regional carbon sequestration (Figure 1): a northern mixed-grass-prairie site near Chugwater $\left(41^{\circ} 29.73^{\prime} \mathrm{N}, 104^{\circ} 45.65^{\prime} \mathrm{W}\right)$, and a sagebrush-steppe site in the Shirley Basin $\left(42^{\circ} 18.3^{\prime} \mathrm{N}, 106^{\circ} 41.9^{\prime} \mathrm{W}\right)$. The elevation of the mixed-grass prairie site is $1750 \mathrm{~m}$ and averages $390 \mathrm{~mm}$ annual precipitation, whereas the elevation of the sagebrush-steppe site is $2200 \mathrm{~m}$ and averages $240 \mathrm{~mm}$ annual precipitation. At the mixed-grass prairie site, the dominant species are Bouteloua gracilis, Calamovilfa longifolia, Achnatherum hymenoides, Pascopyrum smithii, and Hesperostipa comata. Dominant species at the sagebrush-steppe site are Artemisia tridentata subsp. wyomingensis (Wyoming big sagebrush), Pseudoroegneria spicata, Astragalus miser, and Poa cusickii.

During 1999, instantaneous measurements of NEE were made from the Wyoming King Air aircraft on different dates from May to September (Hunt and others 2002, Kelly and others 2002, Smith and others 2003) and were related to aircraft NDVI data to determine $\varepsilon$. The aircraft was flown about 60-90 $\mathrm{m}$ above ground level multiple times along 20- to $25 \mathrm{~km}$-long flightlines (Kelly and others 2002). The aircraft was flown over the sagebrush-steppe site 11 times and over the mixedgrass prairie site 10 times; the multiple passes on a single date were averaged together for an mean daytime NEE (Kelly and others 2002). The exact areas of the four sites (Figure 1) were defined as being within a $2.5 \mathrm{~km}$ border around the flightlines, which was assumed to be the footprint of an eddy-flux measurement system. The radiant flux densities $\left(\mathrm{Wm}^{-2}\right)$ of Red and NIR wavelengths [channels C (630-686 nm) and D (762-898 nm), respectively] were measured using a handheld radiometer (model 100BX, Exotech, Inc., Gaithers- 


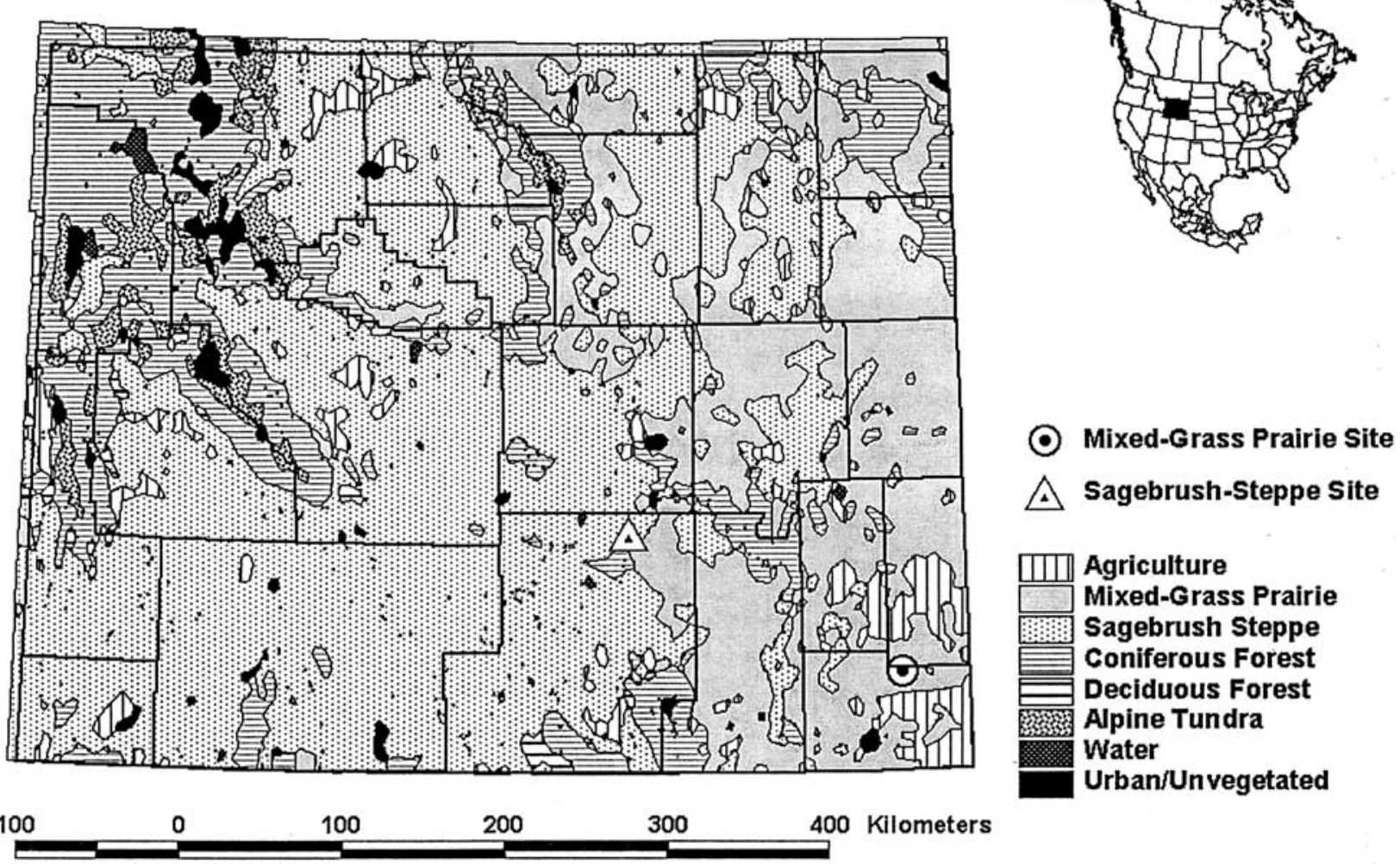

Figure 1. Wyoming landcover map and location of the two study sites in the southeastern portion of the state, a northern mixed-grass prairie site and a sagebrush-steppe site. The state landcover map was derived from Landsat Thematic Mapper data (Driese and others 1997). The inset figure (top, right) shows the location of Wyoming (shaded) in North America.

burg, Maryland, USA), mounted in the nose of the aircraft. These data were corrected for the irradiances of red and NIR radiation based on an up-looking pyranometer (model PSP, Eppley Laboratory, Inc. Newport, Rhode Island, USA) mounted on the top of the aircraft. Data from both the up-looking PSP pyranometer and downlooking Exotech were carefully examined, removing values when the roll, pitch, and yaw of the aircraft exceeded narrow limits; the NDVI data were averaged by flightline to correspond with the eddy-flux measurements (Kelly and others 2002, Smith and others 2003).

The fractions of Red, NIR, and PAR radiation to total solar radiation were calculated from the spectral irradiances measured using a spectroradiometer. (model LI-1800, Li-Cor, Inc., Lincoln, Nebraska, USA). At the same time, solar irradiances were measured using a second Eppley PSP pyranometer. These data were acquired at different times of the day on 14 different days from May through August 1999, at different loca- tions in southeastern Wyoming. Both sensors were calibrated in the spring of 1999 by the manufacturers.

AVHRR data were acquired from the United States Geological Survey EROS Data Center (Sioux Falls, SD, USA for 1995 through 1999. These data are similar to the conterminous US AVHRR data sets (Eidenshink 1992), with the exception that the composites for 1998 and 1999 were done weekly instead of biweekly. Coverage began in late March and finished in early November. For each composite period, the median value of NDVI was used from nearly cloud-free images for the 120 to $1501-\mathrm{km}^{2}$ pixels covering the footprint of the eddy-flux system in the Wyoming King Air aircraft. For weekly composites from 1998 and 1999, there were many weeks that cloud cover affected NDVI; for these weeks, the average of the NDVI for the week before and the week after was used instead.

Intensive study sites were established near the flightline midpoints for the two sites, where $\mathrm{CO}_{2}$ flux mea- 
surements were made using enclosed ecosystem chambers. The sites were sampled every two to three weeks from 1998 through 1999. There were six replicate plots for the mixed-grass prairie site and 12 plots for the sagebrush-steppe site. Six of the 12 plots contained a mature sagebrush shrub and the other six plots were located between sagebrush shrubs. Each plot was fitted the day before with a $1-\mathrm{m}^{2}$ ground area collar that cut about $5 \mathrm{~cm}$ into the soil. Transparent chambers attached to the collars and a gas exchange system (model LI-6200, Li-Cor, Inc., Lincoln, Nebraska, USA) was used to measure NEE six times daily (Welker and others 1999, 2000). After NEE was measured, opaque chambers were attached to the collars and $R_{\text {total }}$ was measured. The daytime measurements of NEE taken during the growing season (May through August) were used to determine $\varepsilon$ using equation 6 . The $R_{\text {total }}$ measurements over a 24-hour period were averaged to obtain the daily average rate. Because respiration rates are an exponential function of temperature, $\ln$ (daily average rate) was regressed against average daily temperature, defined as the average of the minimum and maximum air temperatures.

Simple linear regressions of NEE versus APAR were used to determine the slope $(\varepsilon)$ and intercept $\left(R_{\text {total }}\right)$ according to equation 6 . These regressions were used both for the instantaneous aircraft flux data and the daily flux data from the enclosed ecosystem chambers. The level of significance was set at $\alpha \leq 0.05$ for all statistical tests. Dummy variable and interaction terms were included in multiple linear regressions to test whether the sites had statistically different regression coefficients (Chatterjee and Price 1977). The independent dummy variable had the value of 1 for the prairie site and 0 for the sagebrush-steppe site. A $t$ test, from the slope or intercept and its standard error, was used to test significance of the regression coefficients (Chatterjee and Price 1977).

Carbon sequestration was predicted for 1995 to 1999 using meteorological data acquired from National Weather Service stations in Chugwater and Shirley Basin, Wyoming. Daily solar irradiances $\left(\mathrm{MJm}^{-2}\right.$ day $\left.^{-1}\right)$ were calculated from the meteorological data using a model by Winslow and others (2001). Values of incident PAR were calculated from the weekly average solar irradiance multiplied by the fraction of PAR to solar radiation. From about week 13 to 43, AVHRR NDVI data were used to estimate GPP from equation 4 . When NDVI data were not available (weeks 1-12 and 44-52), GPP was assumed to be zero. Daily $R_{\text {total }}$ was calculated from average daily temperature using a regression equation developed from the chamber measurements.

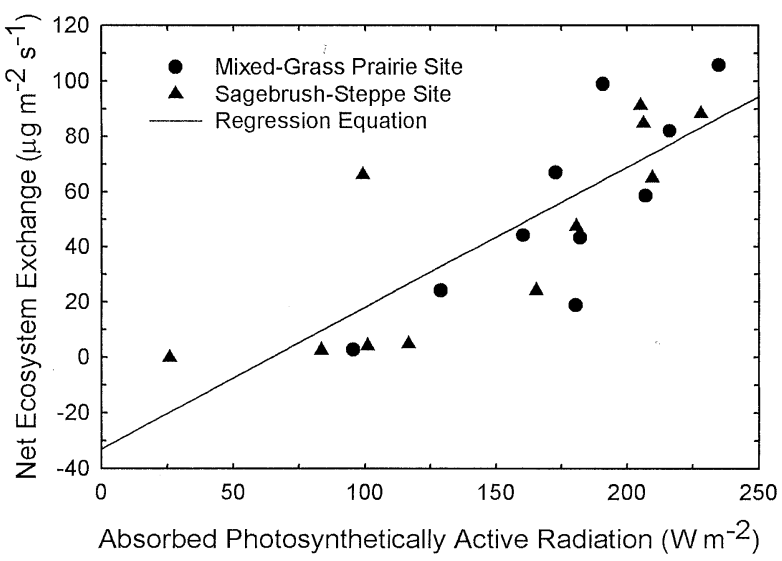

Figure 2. Relationship between instantaneous net ecosystem exchange (NEE) of $\mathrm{CO}_{2}$ measured by the aircraft eddy-covariance flux technique to absorbed photosynthetically active radiation (APAR) for the mixed-grass prairie and sagebrushsteppe study sites. The eddy-flux measurements were acquired from mid-morning to noon and represent the mean of three to five overflights on a given day. The data were combined because the regression equations were not significantly different. The slope $( \pm \mathrm{SE})$ of the regression is equivalent to 0.51 $( \pm 0.7) \mathrm{g} \mathrm{C} / \mathrm{MJ}$ APAR; $R^{2}=0.64$, and $P>0.9999$.

Annual NEE was calculated from the annual totals of GPP and $R_{\text {total }}$ using equation 5 .

\section{Results and Discussion}

\section{Aircraft and Chamber NEE Data}

Values of NEE obtained from the aircraft are linearly related to APAR (Figure 2). From the slope of the regression, $\varepsilon$ was $0.51 \pm 0.07 \mathrm{~g} \mathrm{C} / \mathrm{MJ}$ APAR (slope \pm $\mathrm{SE})$. No significant differences were found between $\varepsilon$ for the mixed-grass prairie and sagebrush-steppe sites, so the data were combined across sites. Furthermore, the chamber values of NEE during 1998 and 1999 were also linearly related to APAR with a slope of $0.64 \pm$ $0.15 \mathrm{~g} \mathrm{C} / \mathrm{MJ}$ APAR (Figure 3). There were no significant differences between $\varepsilon$ for the two sites or the two years. Because $\varepsilon$ does not have units of area, the relationship between NEE and APAR presented in equation 6 may be independent of spatial scale for homogeneous areas. The similarity of $\varepsilon$ between chamber measurements and aircraft flux measurements supports this suggestion.

The average ratio of PAR to total solar irradiance was $0.44 \pm 0.04$ (mean $\pm \mathrm{SD}$ ). For radiometer channels C and $\mathrm{D}$, respectively, the average fraction of red radiation was $0.078 \pm 0.008$, and the average fraction of NIR radiation was $0.13 \pm 0.01$. These values were used to 


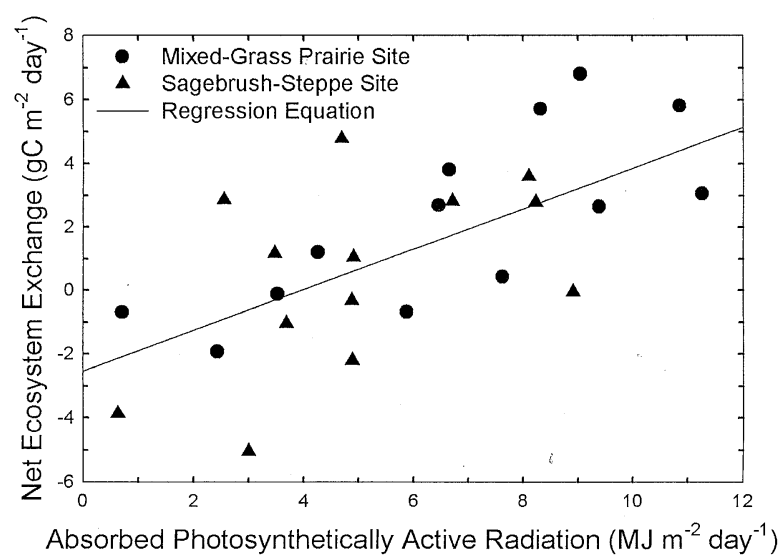

Figure 3. Relationship between daily net ecosystem exchange (NEE) of $\mathrm{CO}_{2}$ measured by the ecosystem chamber technique to daily absorbed photosynthetically active radiation (APAR) for the mixed-grass prairie and sagebrush-steppe sites. The data were combined because the regression equations were not significantly different. The slope $( \pm \mathrm{se})$ of the regression is $0.64( \pm 0.15) \mathrm{g} \mathrm{C} / \mathrm{MJ}$ APAR; $R^{2}=0.44$, and $P>0.999$.

correct NDVI measured from the radiometer on board the aircraft for the regression in Figure 2.

The cool air temperatures in southeastern Wyoming are favorable for high quantum yields, so a reasonable maximum value of $\varepsilon$ for gross photosynthesis should be about $3.0 \mathrm{~g} \mathrm{C} / \mathrm{MJ}$ APAR. When the maximum value of $\varepsilon$ is reduced $50 \%$ to account for light saturation (Ruimy and others 1995), $\varepsilon$ should be about $1.5 \mathrm{~g} \mathrm{C} / \mathrm{MJ}$ APAR. The difference between 1.5 and the value of 0.51 determined from the aircraft NEE data (Figure 2), or the value of 0.64 determined from the chamber NEE data (Figure 3), may be attributable to nutrient limitations or climatic reductions of gross photosynthesis. Models such as BIOME-BGC (Hunt and Running 1992, Running and Hunt 1993, Hunt and others 1996) may be used to assess variability in $\varepsilon$ caused by climate and nutrients for rangeland ecosystems.

The chamber measurements of respiration were obtained during the wintertime and nighttime and, hence, were used in a regression with daily average temperature. The regression equations of $\ln$ (rate) versus daily average temperature for the two sites were not significantly different, so the data were combined for the final equation (Figure 4). The slope of the $\operatorname{In}$ (rate) versus temperature is equivalent to a $Q_{10}$ of 2.2, a reasonable value, although it is somewhat higher than the average $Q_{10}$ of about 2.0 obtained by Raich and Schlesinger (1993).

Soil moisture is also known to be an important predictor of ecosystem $\mathrm{CO}_{2}$ exchange rates, but soil moisture content was not a statistically significant indepen-

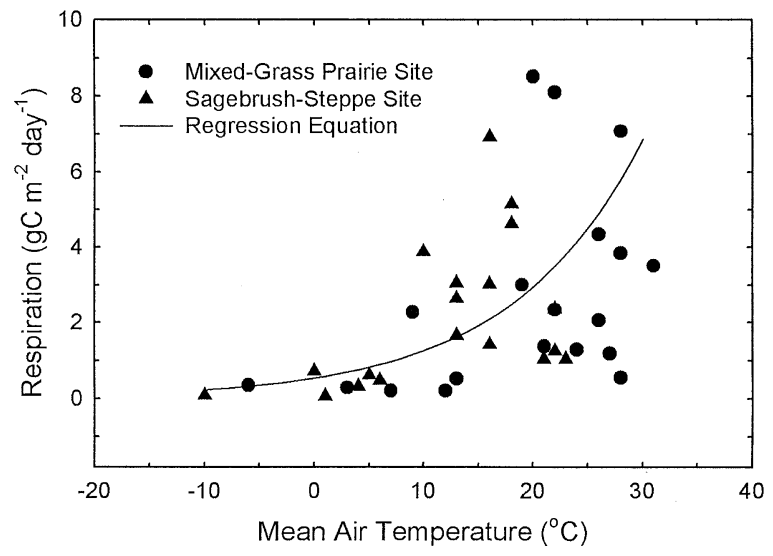

Figure 4. Daily respiration versus average daily air temperature for the prairie and sagebrush-steppe sites. Total respiration, including both autotrophic and heterotrophic respiration, was measured using opaque chambers during a 24-hour period. The data were combined because the regression equations were not significantly different. $R^{2}=0.49$ for a regression using $\operatorname{In}$ (daily respiration) and $P>0.999$.

dent variable at our study sites. Most of the precipitation at these two sites is received during the spring and summer, when soils are warm, so there is a large covariance between temperature and soil moisture. This may not be true for other locations so more comprehensive models of ecosystem respiration will be required. Permanent above-ground biomass is another important variable for respiration (Hunt 1994). However, for rangeland ecosystems, most of the autotrophic biomass is below ground (Jackson and others 1996), so variations in above-ground biomass will have only a small effect on the carbon fluxes.

The original study plan included agricultural and forest sites (Kelly and others 2002), which were not used in this study because we did not have the necessary ground measurements. Furthermore, the agricultural site was in an exhaust plume from a coal-fired electric generation plant, and so the aircraft NEE data were not usable. The aircraft data for the forest site showed that NEE was not significantly related to APAR, but was strongly related to the surface temperature and the vapor pressure difference between the leaf and atmosphere (Kelly and others 2002).

Why would the relationship between NEE and APAR be linear for the two rangeland sites and not for the forest site? Various models of $\varepsilon$ such as Glo-PEM (Prince and Goward 1995, Goetz and Prince 1999) and 3-PG (Waring and others 1995, Landsberg and Waring 1997) are strongly dependent on vapor pressure difference between the leaf and atmosphere, because photosynthesis can not proceed if stomata are closed. In 


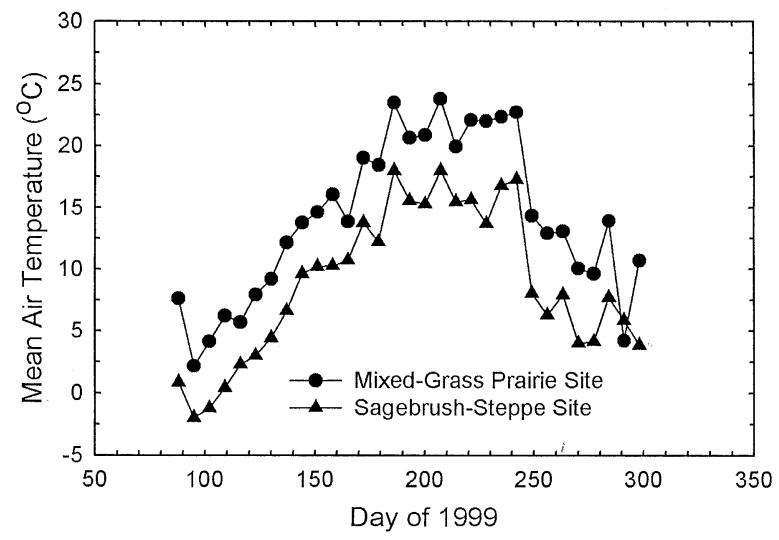

Figure 5. Weekly average of the mean daily air temperature for the mixed-grass prairie and sagebrush-steppe sites during 1999.

forests, stomata are much more sensitive to meteorological conditions, in part because the canopy conductance to water vapor is so large (Jarvis and McNaughton 1986). Rangeland vegetation is short-statured, so the canopy conductance to water vapor is small; hence, rangeland vegetation is uncoupled from atmospheric conditions and strongly coupled to absorbed radiation (Jarvis and McNaughton 1986). Therefore, NEE data may be useful for obtaining $\varepsilon$ only for short-statured vegetation such as rangeland ecosystems.

\section{Carbon Sequestration}

The sagebrush-steppe site generally had cooler temperatures than the mixed-grass prairie site (Figure 5), which is expected from the difference in site elevations. For 1995 to 1999 , the mixed-grass prairie site was the to green-up in the spring, as indicated by AVHRR NDVI (Figures 6 and 7). The NDVI at the sagebrush-steppe site decreased earlier than the mixed-grass prairie site, reflecting the earlier senescence of herbaceous vegetation due to drought and cooler temperatures. Thus, the cooler temperatures at the sagebrush-steppe site should result in lower respiration rates, which would increase NEE, and the shorter growing season should result in reduced GPP, which would lower NEE.

Predictions of weekly NEE generally followed the pattern of NDVI in 1999 (Figures 6 and 7), except during the summer at the mixed-grass prairie site when high air temperatures probably reduced the values of NEE by increased respiration. Predicted NEE for both sites was similar to measured NEE from the aircraft (Figures 6 and 7). Some of the absolute differences may be large ( 2 to $3 \mathrm{~g} \mathrm{Cm}^{-2} \mathrm{day}^{-1}$ ) for a given date, which may be misleading because the predictions were determined weekly, and these ecosystems can be very dynamic, as shown by the weekly NDVI differences.
The annual sums of predicted GPP, $R_{\text {total }}$, and NEE for each site for 1995 to 1999 are shown for the mixed-grass prairie site (Table 1) and for the sagebrush-steppe site (Table 2). During the five years, the mixed-grass prairie site was nearly in carbon balance and the sagebrushsteppe site was a small carbon sink. Surprisingly, no simple relationship was found between annual GPP or annual NEE with annual precipitation for either the mixed-grass prairie or sagebrush-steppe sites (Tables 1 and 2, respectively). The years of 1996 and 1999 both had below-normal annual precipitation. However, in 1996 predicted GPP was lower than average, whereas in 1999 predicted GPP was higher than average (Tables 1 and 2). The high GPP in 1999 was probably due to the timing of precipitation in the late summer that extended the growing season. This explanation is corroborated by the analysis of the differences between $\mathrm{CO}_{2}$ exchange rates observed in the transparent compared to the opaque chambers (Fahnestock and Welker unpublished data). The AVHRR NDVI records the combined effects of seasonal changes in climate and other factors on vegetation growth, which may not be apparent in annual totals.

\section{Conclusions}

Based on AVHRR NDVI and climate data, the values of GPP and $R_{\text {total }}$ were calculated for a mixed-grass prairie site and a sagebrush-steppe site in southeastern Wyoming. Our analysis showed that from 1995 to 1999 the mixedgrass prairie site was in carbon balance and the sagebrush-steppe site was a net carbon sink. These conclusions can not be extrapolated to all grassland and shrubland ecosystems because these predictions were made for specific locations in Wyoming during a specific time period. Because radiation use efficiencies were about equal, we can conclude that the differences in carbon sequestration between the two sites were not likely the result of physiological differences. Because autotrophic respiration depends on GPP, and because heterotrophic respiration depends on litterfall set by net primary production, climatic reductions in GPP would also reduce the rates of autotrophic and heterotrophic respiration over the long term. Eliminating these two alternatives leaves open the possibility that the differences in carbon sequestration between these two sites may have been caused by different land use histories.

Many research programs are focused on testing complex ecosystem models with data from flux networks and then using these complex models to make spatial predictions of carbon sequestration. Remotely sensed data provide necessary inputs, such as ecosystem type and leaf area index, but other required spatial data are poorly known and limit the accuracy of model predic- 

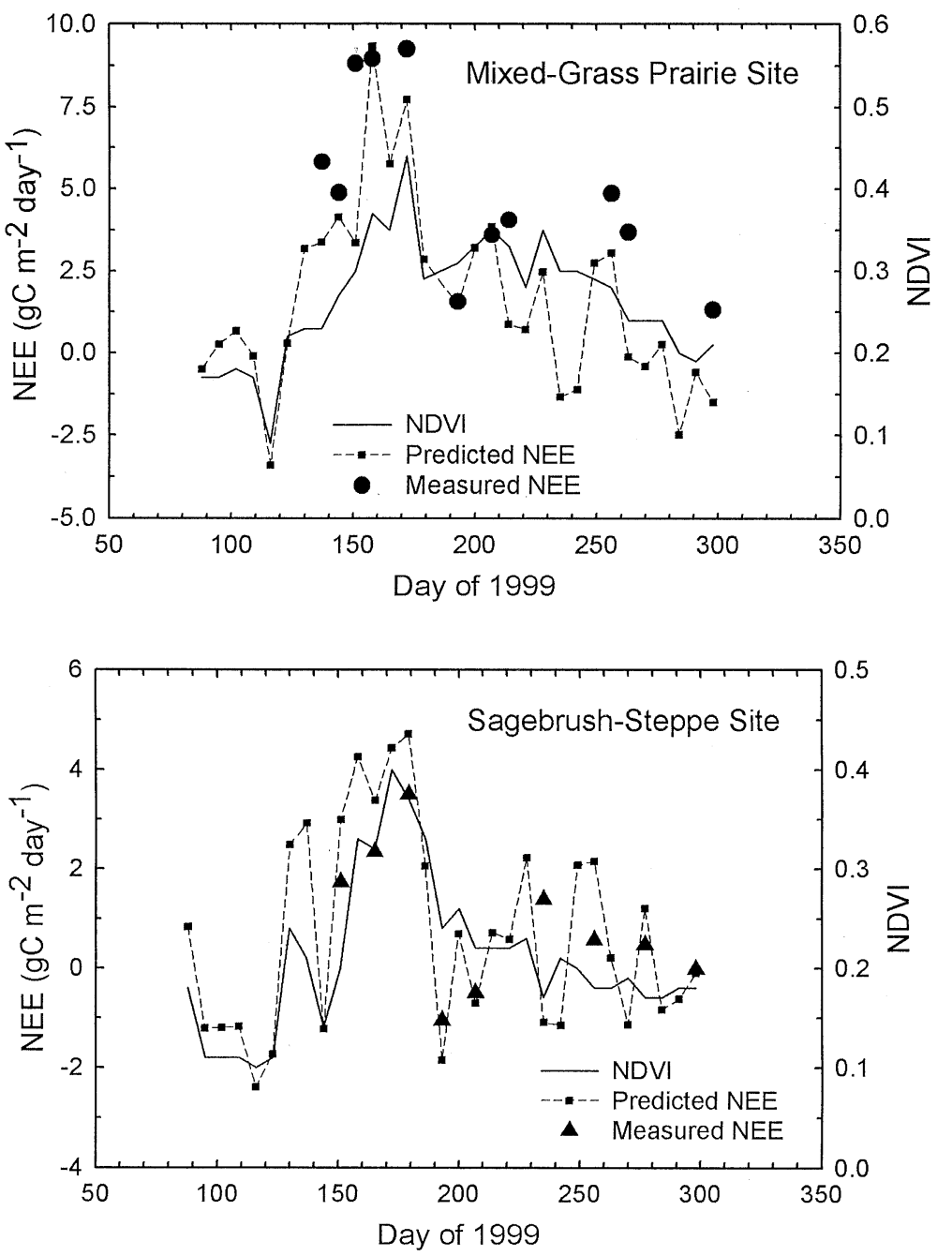

Figure 6. Weekly variation of AVHRR NDVI and predicted daytime NEE for 1999 at the mixed-grass prairie site. Measured daytime NEE are from average of the aircraft flux measurements; predicted NEE is calculated the difference between daily GPP (equation 4) and daytime $R_{\text {total }}$ (calculated from site weather data and the regression equation in Figure 4).
Table 1. Annual precipitation and predicted annual gross primary production (GPP), annual sum of autotrophic and heterotrophic respiration $\left(R_{\text {total }}\right)$, and annual net ecosystem exchange (NEE) for northern mixed-grass prairie site ${ }^{a}$

\begin{tabular}{lllll}
\hline & & \multicolumn{2}{l}{ Carbon $\left(\mathrm{g} \mathrm{Cm}^{-2} \mathrm{yr}^{-1}\right)$} \\
\cline { 3 - 5 } Year & $(\mathrm{mm})$ & GPP & $R_{\text {total }}$ & NEE \\
\hline 1995 & 470 & 305 & 294 & 11 \\
1996 & 377 & 272 & 301 & -29 \\
1997 & 467 & 302 & 300 & 2 \\
1998 & 452 & 313 & 313 & 0 \\
1999 & 364 & 321 & 307 & 14 \\
Mean & 426 & 303 & 303 & 0 \\
\hline
\end{tabular}

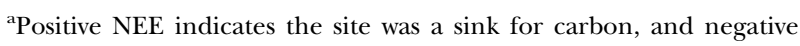
NEE indicates the site was a source for carbon to the atmosphere.

tions. The method proposed here may be accurate because spatial heterogeneity, in part caused by differ-
Table 2. Annual precipitation and predicted annual GPP, $R_{\text {total }}$, and NEE for sagebrush-steppe site.

\begin{tabular}{lllll}
\hline & & \multicolumn{3}{l}{ Carbon $\left(\mathrm{g} \mathrm{Cm}^{-2} \mathrm{yr}^{-1}\right)$} \\
\cline { 3 - 5 } Year & $\begin{array}{l}\text { Precipitation } \\
(\mathrm{mm})\end{array}$ & GPP & $R_{\text {total }}$ & NEE \\
\hline 1995 & 506 & 232 & 189 & 43 \\
1996 & 228 & 214 & 195 & 19 \\
1997 & 306 & 227 & 196 & 31 \\
1998 & 393 & 224 & 206 & 18 \\
1999 & 263 & 239 & 197 & 42 \\
Mean & 339 & 227 & 197 & 30 \\
\hline
\end{tabular}

${ }^{\text {a }}$ Positive NEE indicates the site was a sink for carbon, and negative NEE indicates the site was a source for carbon to the atmosphere.

ent land use histories, is captured with long-term, remotely sensed NDVI.

The method presented here will not work for ecosystems such as forests. For rangelands, however, which have large seasonal changes in NDVI, this method can 
be used to map carbon sequestration, using flux measurements from sites in the USDA-ARS Rangeland $\mathrm{CO}_{2}$ Flux Network and other flux networks. Additional studies are required before operational monitoring of carbon sequestration in rangelands can be performed.

\section{Acknowledgements}

This paper was presented at the USDA Symposium on Natural Resource Management to Offset Greenhouse Gas Emissions in Raleigh, North Carolina, 19-21 November 2002.

This paper was presented at the USDA Symposium on Natural Resource Management to Offset Greenhouse Gas Emissions in Raleigh, North Carolina, 19-21 November 2002.

We thank Brian Miyake for assistance with the AVHRR image processing, Mark McNeal for collection of spectral irradiance and solar irradiance data, and Robert Piper for collection of the chamber flux data. This project was funded by a National Science Foundation grant (IBN9727796) to the University of Wyoming.We thank Brian Miyake for assistance with the AVHRR image processing, Mark McNeal for collection of spectral irradiance and solar irradiance data, and Robert Piper for collection of the chamber flux data. This project was funded by a National Science Foundation grant (IBN-9727796) to the University of Wyoming.

\section{References}

Angell, R., and T. Svejcar. 1999. A chamber design for measuring net $\mathrm{CO} 2$ exchange on rangeland. Journal of Range Management 52:27-31.

Angell, R., T. Svejcar, J. Bates, N. Saliendra, and D. Johnson. 2001. Bowen ratio and closed chamber carbon dioxide flux measurements over sagebrush steppe vegetation. Agricultural and Forest Meteorology 108:153-161.

Asrar, G., M. Fuchs, E. T. Kanemasu, and J. L. Hatfield. 1984. Estimating absorbed photosynthetically active radiation and leaf area index from spectral reflectance in wheat. Agronomy Journal 76:300-306.

Baldocchi, D., R. Valentini, S. Running, W. Oechel, and R. Dahlman. 1996. Strategies for measuring and modelling carbon dioxide and water vapour fluxes over terrestrial ecosystems. Global Change Biology 2:159-168.

Baret, F., and G. Guyot. 1991. Potentials and limits of vegetation indices for LAI and APAR assessment. Remote Sensing of Environment 35:161-173.

Chatterjee, S., and B. Price. 1977. Regression analysis by example. John Wiley \& Sons, New York, , 228 pp.

Cihlar, J., H. Ly, Z. Li, J. Chen, H. Pokrant, and F. Huang. 1997. Multitemporal, multichannel AVHRR data sets for land biosphere studies-artifacts and corrections. Remote Sensing of Environment 60:35-57.
Daughtry, C. S. T., C. L. Walthall, M. S. Kim, E. Brown de Colstoun, and J. E., III McMurtrey. 2000. Estimating corn leaf chlorophyll concentration from leaf and canopy reflectance. Remote Sensing of Environment 74:229-239.

Driese, K. L., W. A. Reiners, E. H. Merrill, and K. G. Gerow. 1997. A digital land cover map of Wyoming, USA: a tool for vegetation analysis. Journal of Vegetation Science 8:133-146.

Eidenshink, J. C. 1992. The 1990 conterminous US AVHRR data set. Photogrammetric Engineering and Remote Sensing 58:809-813.

Follett, R. F., J. M. Kimble, and R. Lal. 2001. The potential of US grazing lands to sequester soil carbon. Pages Pages 401-430 in R. F. Follett, J. M. Kimble, and R. Lal. Eds, The potential of $\mathrm{U} S$ grazing lands to sequester carbon and mitigate the greenhouse effect. Lewis Publishers, Boca Raton, Florida.

Frank, A. B., P. L. Sims, J. A. Bradford, P. C. Mielnick, W. A. Dugas, and H. S. Mayeux. 2001. Carbon dioxide fluxes over three Great Plains grasslands. Pages Pages 167-187 in R. F. Follett, J. M. Kimble, and R. Lal. Eds, The potential of US grazing lands to sequester carbon and mitigate the greenhouse effect. Lewis Publishers, Boca Raton, Florida.

Goetz, S. J., and S. D. Prince. 1999. Modelling terrestrial carbon exchange and storage: Evidence and implications of functional convergence in light-use efficiency. Advances in Ecological Research 28:57-92.

Goulden, M. L., J. W. Munger, S. M. Fan, B. C. Daube, and S. C. Wofsy. 1996. Measurements of carbon sequestration by long-term eddy covariance: methods and a critical evaluation of accuracy. Global Change Biology 2:169-182.

Goward, S. N., and K. F. Huemmrich. 1992. Vegetation canopy IPAR absorptance and the normalized difference vegetation index: An assessment using the SAIL model. Remote Sensing of Environment 39:119-140.

Gower, S. T., C. J. Kucharik, and J. M. Norman. 1999. Direct and indirect estimation of leaf area index, $f_{\text {apara }}$, and net primary production of terrestrial ecosystems. Remote Sensing of Environment 70:29-51.

Gutman, G. G. 1991. Vegetation indices from AVHRR: An update and future prospects. Remote Sensing of Environment $35: 121-136$.

Gutman, G. G. 1999. On the use of long-term global data of land reflectances and vegetation indices derived from the Advanced Very High Resolution Radiometer. Journal of Geophysical Research 104:6241-6255.

Hanson, P. J., N. T. Edwards, C. T. Garten, and J. A. Andrews. 2000. Separating root and soil microbial contributions to soil respiration: A review of methods and observations. Biogeochemistry 48:115-146.

Hunt, Jr, E. R. 1994. Relationship between woody biomass and PAR conversion efficiency for estimating net primary production from NDVI. International Journal of Remote Sensing 15:1725-1730.

Hunt Jr., E. R., J. H. Everitt, J. C. Ritchie, M. S. Moran, D. T. Booth, G. L. Anderson, P. E. Clark, and M. S. Seyfried. 2003. Applications and research using remote sensing for rangeland management. Photogrammetric Engineering \& Remote Sensing 69(6):675-693.

Hunt Jr., E. R., J. T. Fahnestock, R. D. Kelly, J. M. Welker, 
W. A. Reiners, and W. K. Smith. 2002. . Pages Pages 161-174 in R. S. Muttiah Eds, From laboratory spectroscopy to remotely sensed spectra of terrestrial ecosystems. Kluwer Academic Publishers, Dordrecht, The Netherlands.

Hunt Jr., E. R., S. C. Piper, R. Newmani, C. D. Keeling, R. D. Otto, and S. W. Running. 1996. Global net carbon exchange and intra-annual atmospheric $\mathrm{CO}_{2}$ concentrations predicted by an ecosystem process model and three-dimensional atmospheric transport model. Global Biogeochemical Cycles 10:431-456.

Hunt Jr., E. R., and S. W. Running. 1992. Simulated dry matter yields for aspen and spruce stands in the North American boreal forest. Canadian Journal of Remote Sensing 18:126-133.

Jackson, R. B., J. Canadell, J. R. Ehleringer, H. A. Mooney, O. E. Sala, and E. D. Schulze. 1996. A global analysis of root distributions for terrestrial biomes. Oecologia 108:389-411.

Jarvis, P. G., and K. G. McNaughton. 1986. Stomatal control of transpiration: scaling up from leaf to region. Advances in Ecological Research 15:1-49.

Kelly, R. D., E. R. Hunt Jr., W. A. Reiners, W. K. Smith, and J. M. Welker. 2002. Relationships between daytime carbon dioxide uptake and absorbed photosynthetically active radiation for three different mountain/plains ecosystems. Journal of Geophysical Research 107(D14):19.1-19.8.

Landsberg, J. J., and R. H. Waring. 1997. A generalised model of forest productivity using simplified concepts of radiationuse efficiency, carbon balance and partitioning. Forest Ecology and Management 95:209-228.

Myneni, R. B., and D. L. Williams. 1994. On the relationship between FAPAR and NDVI. Remote Sensing of Environment 49:200-211.

Paustian, K., C. V. Cole, D. Sauerbeck, and N. Sampson. 1998. $\mathrm{CO}_{2}$ mitigation by agriculture: an overview. Climatic Change 40:135-162.

Prince, S. D. 1991. A model of regional primary production for use with coarse resolution satellite data. International Journal of Remote Sensing 12:1313-1330.

Prince, S. D., and S. N. Goward. 1995. Global primary production: a remote sensing approach. Journal of Biogeography 22:815-835.

Raich, J. W., and W. H. Schlesinger. 1993. The global carbon dioxide flux in soil respiration and its relationship to vegetation and climate. Tellus B44:81-99.

Rouse, J. W., R. H. Haas, J. A. Schell, D. W. Deering, and E. P. Mercanti. 1974. Monitoring vegetation systems in the Great Plains with ERTS. Pages Pages 309-317 in S. C. Freden, and M. Becker. Eds, Third earth resources technology satellite-1 syposium, volume I: technical presentations. NASA SP-351, National Aeronautics and Space Administration, Washington, D.C.

Ruimy, A., G. Dedieu, and B. Saugier. 1994. Methodology for the estimation of terrestrial net primary production from remotely sensed data. Journal of Geophysical Research 99:5263-5283.

Ruimy, A., P. G. Jarvis, D. D. Baldocchi, and B. Saugier. 1995. $\mathrm{CO}_{2}$ fluxes over plant canopies and solar radiation: A review. Advances in Ecological Research 26:1-66.
Ruimy, A., L. Kergoat, C. B. Field, and B. Saugier. 1996. The use of $\mathrm{CO}_{2}$ flux measurements in models of the global terrestrial carbon budget. Global Change Biology 2:287-296.

Running, S. W., and E. R. Hunt Jr. 1993. Generalization of a forest ecosystem process model for other biomes, BIOMEBGC, and an application for global-scale models. Pages Pages 141-158 in J. R. Ehleringer, and C. Field. Eds, Scaling physiological processes: leaf to globe. Academic Press, San Diego.

Running, S. W., D. D. Baldocchi, D. P. Turner, S. T. Gower, P. S. Bakwin, and K. A. Hibbard. 1999. A global terrestrial monitoring network integrating tower fluxes, flask sampling, ecosystem modeling and EOS satellite data. Remote Sensing of Environment 70:108-127.

Sellers, P. J., F. G. Hall, G. Asrar, S. E. Strebel, and R. E. Murphy. 1992. An overview of the First International Satellite Land Surface Climatology Project (ISLSCP) Field Experiment (FIFE). Journal of Geophysical Research 97:18345-18371.

Sellers, P. J., F. G. Hall, R. D. Kelly, A. Black, D. Baldocchi, and J. and others Berry. 1997. BOREAS in 1997: experimental overview, scientific results, and future directions. Journal of Geophysical Research 102:28731-28769.

Sinclair, T. R., and T. Horie. 1989. Leaf nitrogen, photosynthesis, and crop radiation use efficiency: a review. Crop Science 29:90-98.

Sinclair, T. R., and R. C. Muchow. 1999. Radiation use efficiency. Advances in Agronomy 65:215-265.

Smith, W. K., R. D. Kelly, J. M. Welker, J. T. Fahnestock, W. A. Reiners, and E. R. Jr Hunt. 2003. Leaf-to-aircraft measurements of net $\mathrm{CO}_{2}$ exchange in a sagebrush steppe ecosystem. Journal of Geophysical Research 108(D3):15.1-15.9.

Svejcar, T., H. Mayeux, and R. Angell. 1997. The rangeland carbon dioxide flux project. Rangelands 19:16-18.

Waring, R. H., B. E. Law, M. L. Goulden, S. L. Bassow, R. W. McCreight, S. C. Wofsy, and F. A. Bazzaz. 1995. Scaling gross ecosystem production at Harvard Forest with remote sensing: a comparison of estimates from a constrained quantum-use efficiency model and eddy correlation. Plant, Cell and Environment 18:1201-1213.

Welker, J. M., K. B. Brown, and J. T. Fahnestock. 1999. CO 2 flux in arctic and alpine dry tundra: comparative field responses under ambient and experimentally warmed conditions. Arctic, Antarctic and Alpine Research 31:308-313.

Welker, J. M., J. T. Fahnestock, and M. H. Jones. 2000. Annual CO2 flux from dry and moist arctic tundra: field responses to increases in summer temperature and winter snow depth. Climatic Change 44:139-150.

Winslow, J. C., E. R., Jr Hunt, and S. C. Piper. 2001. A globally applicable model of daily solar irradiance estimated from air temperature and precipitation. Ecological Modelling 143:227-243.

Wylie, B. K., D. A. Johnson, E. Laca, N. Z. Saliendra, T. G. Gilmanov, B. C. Reed, L. L. Tieszen, and B. B. Worstell. 2003. Calibration of remotely sensed, coarse resolution NDVI to $\mathrm{CO}_{2}$ fluxes in a sagebrush-steppe ecosystem. Remote Sensing of Environment 85:243-255. 